\title{
Disciplinary Boundaries in Question: Balkan Studies in a Globalizing World
}

\author{
Karl Kaser \\ Graz
}

The disciplinary boundaries between Balkan Studies and Near East and/or Middle East Studies ${ }^{1}$ were basically drawn in the course of the $19^{\text {th }}$ and the beginning of the $20^{\text {th }}$ century within a certain political framework and as results of European political interests. Arabic and Islamic Studies were considered as the study of the culturally and religiously other. Balkan Studies in this period of time were conceived as "the orient within"2. The dissolution of the Habsburg and the Ottoman Empires by the end of World War I changed the political landscape. Near East Studies received the flavour of British and French Colonial Studies, whereas the German Reich was interested to explore the designated food deliverer, the Balkans, within its concept of Großraumpolitik.

After 1945 the situation again changed for area studies in the Balkans and the Near East. The emerging Cold War created a completely new constellation. The Near East was disposed of colonialism; the USA jumped in and began to keep the region under its control. The Balkans, except Greece, was lost to the communist world. Separate Balkan Studies and Near East Studies in the West as well as in the East became legitimized by the Cold War.

The Cold War is over; we are living increasingly in one, globalizing world and the former well, however ideologically defined regions have

\footnotetext{
${ }^{1}$ Anglo-American academia prefers the term 'Middle East', which denominates the Islamic world from North Africa to Pakistan/Afghanistan and which shared the destiny of being colonized. The German speaking world prefers the term 'Near East', which usually comprises the Asian territories of the former Ottoman Empire. Since my paper refers to these territories I prefer 'Near East'.

${ }^{2}$ Quote taken from Neuburger's book (Neuburger 2004).
}

become arbitrary. The Bosporus, the Danube, and other waterways cannot any longer constitute borderlines of scholarly disciplines. The Balkans has always been linked to Central Europe, the Mediterranean, Eastern Europe and especially the Near East, and is increasingly linked to the rest of the world. Interestingly enough, the historical entanglement of the Balkans with Central Europe has been paid great attention in the previous two decades and its intersections with Eastern Europe and the Mediterranean has been fairly investigated. However, the Balkans' shared history with the Near East ${ }^{3}$ has been almost completely ignored, which is also the case with the Balkans' position in global history. ${ }^{4}$

Area studies or regional studies as university disciplines in full scale are mostly undertaken in states that have global interests such as the USA but also Great Britain, Germany or France; more specific area studies are conducted in states that have narrowly defined regional interests such as Austria in the Balkans and Central Europe. Common to all area studies is intensive language study, in-depth field research, close attention to local history, and testing grounded theory against detailed information. They try to bring in their findings to general theoretical backgrounds, they are tending to be inter- or multidisciplinary and the boundaries of area studies fields are usually historically contingent and, therefore, highly contestable under present conditions. ${ }^{5}$

\footnotetext{
${ }^{3}$ Among the few exceptions are Schevill 1922; Inalcik 1993; Brown 1996; Kaser 2011; Ginio/Kaser 2013.

${ }^{4}$ The title of Wachtel's book 'The Balkans in World History' (Wachtel 2008) promises this but the contents contradict the promise.

${ }^{5}$ Szanton 2003; Schäbler 2007, 12.
} 
This article addresses four problems. The first, general one, discusses the never-ending challenges of area studies; the second, still general, analyses the challenge of globalization for area studies, the third, more specifically, pays attention to the global history approach for historical area studies and the fourth questions the heuristic value of geographical terms such as 'Southeastern Europe' and 'Balkans' and pleads in favor of considering the Balkans and the Near East (Eurasia Minor) a single historical world region.

\section{Never-ending Challenges of Area Studies}

Area studies have always reflected not only intellectual interests but also those of states and international politics. The latter two make them vulnerable against changing political contexts and interests. Beyond traditional and latent criticism of area studies of being parochial, globalization has become a new challenge for area studies. Before coming to this new challenge, the traditional arguments against area studies are going to be summarized. There are almost half a dozen of them:

(1) One of the fundaments of European Enlightenment was to study universal principals and to investigate the universal in specific contexts. The birth of area studies began with the Enlightenment's efforts to underpin theories of human progress by comparing Western Europe to other regions of the world. ${ }^{6}$ Still, a body of knowledge is produced mostly by Western scholars for Western audiences about non-Western societies, cultures and histories. Scholars represent the non-West in convenient ways. ${ }^{7}$ The legitimacy of Euro-centrism and US-centrism has become under significant pressure.

(2) Area studies in the USA were not a direct result of Cold War but emerged already in the 1930s. For instance, oriental studies which had developed out of biblical studies comprising art, archeology, political science, language, literature, and sociology. ${ }^{8}$ The post-World War II project of area studies was an attempt to delineate relatively large geographic regions that

\footnotetext{
${ }^{6}$ Ludden 2003, 131.

${ }^{7}$ Mirsepassi et al. 2003, 1.

${ }^{8}$ Mitchell 2003, 149.
}

possessed some cultural, historic, and linguistic coherence: former Soviet Union, Southeast Asia, East and Central Europe, and, much later, West Europe. By 1995 the main sponsors of area studies, the Social Science Research Council and the American Council of Learned Societies abandoned the world areas approach and disbanded the Joint Committees organized by world areas. World areas were considered inadequate models for understanding the world. ${ }^{9}$ Programs of revitalizing area studies ${ }^{10}$ are counteracted by the actual world economy crisis, which touches the funding of area study programs at US universities immensely.

(3) The crisis of area studies is also understood as the problem of how area fields are related to the academic disciplines. The disciplinary homes called the area studies back to more serious sites of scholarship - and to be more universal. Transnational forces and identities are said to be one of the major factors placing the future of area studies in question. The current problems of area studies arise to a significant extent also from the crisis in social sciences in general, but especially in political sciences. There is the certainty of a universal knowledge of politics. But even the theoretical political scientists find it difficult to abandon the need for the kind of local political understanding traditionally supplied by area research. Such regional or cultural 'anomalies' are called now the 'institutional form' of a universal phenomenon. ${ }^{11}$

(4) Area studies programs are sometimes considered as weak and scattered enclaves. They allegedly have no theories of itself for its self-protection and no intellectual mastery of its own fate. They have not bothered even to describe area specific knowledge as such. A broadly based theory for area studies would require a kind of collaboration of area specialists that does not yet exist. ${ }^{12}$

(5) The reality and analytical value of the old geo-political area studies has not completely disappeared. But many boundaries have become much more permeable, and the importance of sometimes new, sometimes longstanding transnational social, economic and cultural forma-

\footnotetext{
${ }^{9}$ Mirsepassi et al. 2003, 2, 4; Green 2003, 137.

${ }^{10}$ Tessler et al. 2001, 71 .

${ }^{11}$ Mitchell 2003, 159-162.

${ }^{12}$ Ludden 2000.
} 
tions is increasingly being recognized. ${ }^{13}$ Since the 1970s, area studies had to learn that geographically fixed areas do not correspond with social reality.

To conclude, traditional world area studies have experienced a crisis in the previous two decades because the world has changed fundamentally with the end of the Cold War and the intensification of globalization and de-territorialization of cultures. Accused of being essentialist and of constructing the area they study, area studies were abandoned to a large degree in countries such as the USA. This trend, however, is not a universal one. At European universities, for instance, area studies are better rooted and enjoy more continuity. It is my impression that currently exist more Balkan study centers than two decades ago. As it looks like, area studies such as Balkan studies and East European studies have received a new momentum since they have been exposed to the challenges of global studies. Global studies cannot exist without receiving fresh impulses from area studies.

\section{The Challenge of Globalization}

'Globalization' is not precisely defined; it includes international forces - technological, economic, and cultural - that are driving more and more developments in the world around us. ${ }^{14}$ Global capital in its contemporary form is characterized by strategies of predatory mobility (across both time and space). States have eroded as sites of political, economic, and cultural sovereignty. ${ }^{15}$ Globalization is broadly seen as erasing boundaries, as de-territorialization, and forces the homogenization of localities, cultures, and social and economic practices. ${ }^{16}$

Historians often smile about the sudden intensification of the globalization debate because for them this process has already taken a long time. From the global historian's perspective 'globalization' refers to a bundle of related processes (commerce, technology, state organization, culture) that do not progress at the same speed or move in the same direction and do not affect

\footnotetext{
13 Szanton 2003.

${ }^{14}$ Ludden 2000.

${ }^{15}$ Appadurai 2001, 17.

${ }^{16}$ Szanton 2003
}

the various parts of the world in the same way. ${ }^{17}$ Osterhammel and Petersson see in the establishment of the Portuguese and Spanish colonial empires around 1500 the onset of an uninterrupted process of globalization and irreversible process of worldwide integration. ${ }^{18}$ This process has been accelerating significantly since 1989 . We as scientists at a certain age are witnesses of the parallelism of the demise of Communism and the popularization of the PC. I bought my first PC in 1989. Globalization since then has been co-created by social sciences, whereas, parallel to that, social sciences have been driven by globalization. Especially area studies, geographically based, are touched by it.

There are good reasons to oppose globalization and its negative side-effects, on the one hand; on the other hand, it would be unjustifiable not to react to this emerging challenge. With regard to the US based area studies, the challenge consists in:

1) Area-based knowledge in a globalizing world has seemingly become irrelevant. The USgovernments needed knowledge about their potential adversaries and allies in the era of Cold War. Communism, however, has passed; the view on the world has become different and the traditional area studies have become anachronistic. Growing mobility of capital, commodities, images, cultural forms, and of people among different world areas has had important implications for area studies. ${ }^{19}$

(2) Disciplinary universalists argue that globalization is defining a single world zone for the application of universal theory, which makes area studies irrelevant. Territoriality has become more fluid, cultural boundaries are moving, and disciplines are shifting. Now cultural areas do not seem as coherent as they did twenty or forty years ago. Geographies are shifting and the changing substance of cultural areas is now more visible than ever before. The empirical reality of the bounded cultural areas that underpinned area studies is now obviously dubious. The trouble with area studies is a particular configuration of apparent stabilities for permanent associations between space, territory, and cultural organization. ${ }^{20}$

\footnotetext{
${ }^{17}$ Osterhammel/Petersson 2003, vii.

${ }^{18}$ Ibid, 28.

${ }^{19}$ Mirsepassi et al. 2003, 2, 5.

${ }^{20}$ Appadurai 2001, 7-9; Ludden 2003, 132-133.
} 
(3) Cultural areas may be considered little more than constructs of imperialism and nationalism - imagined territories institutionalized by Europe's modernity. Post-structuralism, postmodernism, postcolonial criticism and critiques of development discourse have questioned scientific rationality based on theories of modernity. ${ }^{21}$ Behind that is the idea of stable culture areas projected by Western cartography of large civilizational landmasses with different relationships to Europe. But in the age of globalization - how does the world look from other social, cultural and national locations? Areas are not facts but artifacts of our interests and our fantasies as well as of our needs to know, to remember, and to forget. ${ }^{22}$

(4) The crisis of area studies in the USA is linked with the end of the Cold War, which had made available generous funding for area studies generally. The US appears to be triumphant throughout the world; therefore area studies seem to be unnecessary any longer ${ }^{23}$ needless to mention that this point of view has turned out to be a naïve one. Only after a few months in power, US-President Obama was eager to reconfigure America's position in the world, e.g. by acknowledging Muslim values as equal to western ones.

(5) New modes of knowledge production are needed - more global forms of social science knowledge overt the established configurations of area studies. Area studies are now dubbed in the USA as "context-sensitive social science" - global in its vision, argument, and relevance, local in its data and application. The entire hosts of intermediary territories that lie between the global and the local have almost disappeared in the discourse of globalism. Globalization will obviously not provide a stable and comfortable intellectual or institutional home for area studies scholarship. ${ }^{24}$

(6) Transnationalism as one element of globalization is also challenging the traditional conception of area studies. Especially the variety and increasing international diasporas and networks is emphasizing the importance of new social and cultural formations cross cutting area boundaries. ${ }^{25}$

How did the international scientific areastudies community react to these challenging

\footnotetext{
$\overline{{ }^{21} \text { Ludden 2003, } 134 .}$

22 Appadurai 2001, 9.

${ }^{23}$ Khalidi 2003, 182-183.

${ }^{24}$ Ludden 2000.

${ }^{25}$ Szanton 2003.
}

questions and voices from the USA until now? At first glance, the visible tendencies reformulate traditional area studies into a new form, which poses the research question into the foreground and the traditional areas into the background. This is the case especially with postcolonial as well as with global and globalization studies.

(1) Postcolonial studies. Parallel to the trend towards the global and globalization studies, the master narratives privileging the local, the everyday, and the particular have been questioned by postmodernism and postcolonial scholarship. A great deal of postcolonial theory emerges from a close familiarity with particular regions and is committed to interdiscliplinarity and contextually grounded knowledge. Postcolonial scholars have turned their attention to diasporas, immigrants, and hybrid identities; national boundaries have become frequently irrelevant. Political and cultural territories have become considered as different realms. Whereas area studies confine themselves to the nation-state or the larger region as the only units of analysis, postcolonial studies have neglected them in favour of localglobal connections. ${ }^{26}$

(2) Global or globalization studies. Scholarly interest for globalization is growing - often ignoring the growth of regional and class inequalities. Nevertheless, the increased international flows of capital, labour, products, information, and technology have important implications on area studies. Globalization studies assume and investigate processes that supposedly are creating universals through a single, integrated world system with strongly homogenizing tendencies. However, we cannot speak about a universal modernity but a plurality of modernities. ${ }^{27}$ This leaves room for the possibility of a more locally imagined vision of modernization. Capitalist modernization is consistent with a wide range of social and cultural practices. Local people formulate and implement their own visions of their own futures. The social science vision of comprehensive convergence is an illusion. There is an even greater need for the deep study of specific geographies, histories, and languages. ${ }^{28}$

\footnotetext{
${ }^{26}$ Mirsepassi et al. 2003, 8-10.

${ }^{27}$ Eisenstadt 2000.

${ }^{28}$ Ibid., 10-12.
} 
Beyond this massive growing of postcolonial and global as well as globalization studies, there is wide agreement that area studies have to adjust themselves to these emerging trends by:

(1) A massive effort to establish cooperative links among organizations that emphasize the need to examine the relationships that exist between the local and the global as well as among world areas. ${ }^{29}$

(2) The encouragement of more comparative and thematic research across areas. This would help to determine exactly how different or interconnected areas really are or, to be cautious, imagined. ${ }^{30}$

(3) The encouragement of cross area comparative research seeking broad generalizations and cross-culturally robust theory. ${ }^{31}$

(4) The need of being trained in at least two languages, two histories, and two cultures. ${ }^{32}$

There are sufficient reasons for questioning the traditional outline of area studies. Some of the mentioned reasons are specific for the situation in the USA, others aren't. In Europe, where area studies are better institutionalized, there are, however, not many reasons to be relaxed. Area studies cannot any longer remain isolated container studies but can only survive if they adopt also global perspectives. This assessment holds also for historical area studies.

\section{The Challenge of Global History}

This section refers to the more specific needs of historical area studies, which are also involved in the above mentioned streams of globalization in social sciences. Here, the relationship between the whole and the part, the global and the regional (and topical) wins even more momentum than in other disciplines. In difference to traditional concepts of universal history and/or world history, global history ${ }^{33}$ does basically not intend to comprise the whole history but looks at processes of integration of historical world regions and tries to understand the whole by one of its

\footnotetext{
${ }^{29}$ Green 2003, 139.

${ }^{30}$ Szanton 2003.

${ }^{31} \mathrm{Ibid}$.

${ }^{32}$ Ibid.

${ }^{33}$ About the different concepts of universal history, world history, and global history see Middell 2005.
}

parts. The part can only be determined if there is an idea about its wholeness. The idea that the whole is constituted by the sum of the parts has become obsolete. The whole and the part are rather dialectically related. The hermeneutic circle for historians is still the source of increasing historical knowledge: the area, periodical or topical specialists are dealing with their respective parts; this changes the understanding of the whole, and the changed understanding of the whole changes again the understanding of the part etc. The whole is only an idea, an image, an aim, which creates its relative parts. This circle is endless and the result uncertain. The idea of the whole empirically cannot be realized but enables us to realize global history empirically. ${ }^{34}$

The experience of globalization suggests the global, the world as the constructed whole. Area or regional history and global history are alike the part and the whole; they are constructed and have to be characterized by the historian as such. Global history cannot be considered as the opposite to the regions' history under a geographical umbrella. In times of globalization, the concern for this one and only world has come into the foreground. It is this idea of the one world, which has become also important for historical sciences. The term 'global' substitutes the term of 'general' history, the connotation of which is the existence of an important history - the general one - and of sub-disciplines such as colonial history, women's history or regional history that cannot contribute much to the general one. A global history has to be open and receptive equally for all parts of the whole, which are meaningful: The colonial studies have the right to consider the West as a province among others and neither micro nor macro structures are preferred. ${ }^{35}$

Global history per se cannot be subject of investigation. It can be imagined but not written. It is an idea beyond empirics. As an idea, global history has to be investigated on the basis of concrete topics: processes of globalization, commercial activities, migration flows, or global protest movements. The history of globalization is an important subject but this does not constitute global history. Global history is not a subject but

\footnotetext{
${ }^{34}$ Epple 2007, 101-103.

${ }^{35}$ Ibid. 2007, 100-111.
} 
a certain perspective on history: think global by studying the local. ${ }^{36}$

Schäfer's ${ }^{37}$ approach to the problem of the global and the local is more radical as the just mentioned by going a step further: Not a global future in singular exists from today's perspective but the globality of world regions. Processes of globalization determine the globality of things but, on the other hand, the conditions of being global are different. ${ }^{38} \mathrm{He}$ specifies globalization as "technoscientific civilization" that has begun to cover the globe. Technoscience as a hybrid of scientized technology and technologized science accepted by the different powerful local cultures of the world in sharp contrast to Americanization; it is on the way of becoming the shared context of all cultures. But the user terminals placed around the world are places where global technoscience and local cultures interact; a globally distributed network is used locally according to local and individual needs. This, for instance, may provide new social movements with a global perspective. According to Schäfer's analysis, the future lies in a global civilization with many local cultures and regional futures. ${ }^{39}$

Whereas the post-socialist world is economically and culturally largely integrated in global processes the concepts of how to integrate area studies such as East European history and the history of the Balkans in global history are not yet very advanced. With regard to East European history Stolberg states a considerable desiderate ${ }^{40}$ and Haslinger the very beginning of a debate $^{41}$. Whereas the former sees the future of the integration of East European history into transcontinental studies via a Eurasian research perspective, the latter suggests a stronger integration of East European history into European history as well as into global history as soon as the relationship between global and area history has been clarified. Nolte points at no global history can be written without the research on specific regions and underlines in great detail the specific

\footnotetext{
$\overline{{ }^{36} \text { Epple 2007, 111, } 113 .}$

${ }^{37}$ Wolf Schäfer is an exponent of the New Global History which considers global history as history of globalization beginning with 1950: Rothermund 2005.

${ }^{38}$ Schäfer 2006, 1, 6.

${ }^{39}$ Schäfer 2001, pp. 302, 313; Schäfer 2003, 75.

${ }^{40}$ Stolberg 2007, 1.

${ }^{41}$ Haslinger 2006, 1.
}

role and contribution of Eastern Europe towards global developments until the $19^{\text {th }}$ century. ${ }^{42}$

With regard to the history of the Balkans, Brunnbauer offers an approach that can be easily harmonized with global historical research questions. He argues that in light of previous debates about the definition of the region and about the ingredients that makes it a separate historical region one should avoid this kind of discussion and, instead, conceptualize the Balkans as trans-local space, as a space of various "entanglements, transfers and relations. Historical research thus should reconstruct the relevant spatial dimensions of the relevant matters, and not start by a given spatial - be it national or regional - 'container."' ${ }^{43}$ Instead of looking at space we should concentrate on interaction and communication networks configured by people as well as institutions. The reach of these kinds of networks might be local, global or somewhere in between. Empires and even more nation states were institutions that comprised interaction and communication, Brunnbauer concludes. ${ }^{44}$

To conclude this subchapter, area studies constitute a great chance for global history and vice versa: area studies have the advantage of usually not being Euro-centred. Historical area studies can provide crucial impulses for global history studies; area studies can become impacted by aspects of global history. Especially if we investigate the functioning of globalization, we need specific local/regional knowledge. ${ }^{45}$ The area and the global have to be considered as fluid in historical perspective because historians are drawing always new perspectives on history. Therefore, historical regions as well as cultural areas are not chiselled in stone forever.

\section{The Balkans, the Near East or both?}

I think that the implosion of socialism and the succeedingly unfolding processes of globalization have impacted the concept of Balkan history in two ways: (1) it suggests to conceive the Balkans as trans-local space as pointed out by Brunnbauer; (2) it suggests even more - the con-

\footnotetext{
${ }^{42}$ Nolte 2006.

${ }^{43}$ Brunnbauer 2011, 78.

${ }^{44}$ Ibid, 83-84.

${ }^{45}$ Schäbler 2007, 37.
} 
ceptual reunion of the Balkans and the Near East - a territory that I would suggest to call Eurasia Minor $^{46}$ - and the conception of Eurasia Minor as trans-local space.

This leads us to the self-perception of Balkan or Southeast European studies, which have been uncritically conceived as given since many decades and therefore firmly institutionalized so as if the world around the region would have not changed. In this regard I would suggest to point at the artificiality of historic areas reflected in the separateness of Balkan studies and Near East studies.

Unlike any other region in the world, Eurasia Minor situated between the Tigris and the Danube Rivers, shares a joint history, if we define 'joint history' as embeddedness in politically superior structures over long periods of time. The joint history began in the period of Hellenism (in the last third of the $4^{\text {th }}$ century B.C.), continued with the establishment of the Roman and the Byzantine Empires, and ended with the fall of the Ottoman Empire in early $20^{\text {th }}$ century. The communality of an almost three thousand years' history is obvious, and we have to ask the significant question why this common history has not found its way into historiography as a whole but only periodically and as separated spaces. ${ }^{47}$

There remains hardly any doubt that Eurasia Minor is characterized by all credentials of a world region. World regions are spaces based on joint historical experience and dense interaction. The Hellenistic, Byzantine and Ottoman empires extended their power also over territories which were not under their direct control. Economically, they were characterized by the featurespatially completion of their subspaces and were intertwined with other world regions. They were culturally heterogeneous and diverse. ${ }^{48}$

As already mentioned the establishment of area studies always had also political implications and imaginations. Universities and countries with defined foreign political and economic interests in certain areas have established area studies in the fields of research and training, which usually include social and historical sciences, theological and linguistic studies. At about

\footnotetext{
${ }^{46}$ Kaser 2011, 2.

${ }^{47}$ Ibid.

${ }^{48}$ Categories provided in Komlosy 2011, 169-170.
}

the middle of the $20^{\text {th }}$ century the Near East on the one hand and Eastern and South Eastern Europe on the other were designated as separate 'problem regions' by Western scholars. In the framework of the Cold War, Eastern and South Eastern Europe were integrated into the 'East Block', which was hostile to the 'West Block' and vice versa. The countries of the Near East had successfully stripped off their colonial bounds and in reaction might have looked for assistance by the Soviet Union - and partially received it. In the global context of the Cold War, the West was also eager not to lose its impact, primarily on the Islamic Near East. This constituted the background for the establishment of Near East studies on the one hand and East and Southeast European Studies on the other hand with different intensions and programs. They were, and still are, not related to each other and organize their separate scholarly conferences and journals. Whereas some concentrated on Arabic, Turkish, and Hebrew languages, others focussed on Slavic languages, Hungarian, Romanian or Albanian.

It was not only on the horizontal but also on the vertical-chronological level that the region was sliced into specific disciplines: the Ottomanists tend to focus on the history and culture of the Ottoman part of the Islamic world, the Byzantinists predominantly incorporate research of the Byzantine period into their programs, and the Classic Ancient Studies concentrate on the history and culture of the Greek-Roman period. The Old-Orientalists focus on the pre-classical cultures having stretched from Anatolia to Egypt. Therefore, certain epochs and the Bosporus are separating disciplines, which would be per se closely related. The actual challenge therefore consists, superficially, quite simply in the utilisation of the resources of the historical toolbox to fit certain puzzles together from the different disciplines in order to create a picture of the shared history of the Balkans and the Near East. But this is not as simple as it sounds - on the contrary. The challenge is enormous. As long as we slice disciplinarily a shared history into periods and territories we are hardly fit for debates on global history.

However, in the previous two decades the agenda and the debates of dominating SoutheastEuropeanologists and Balkanologists indicate a deviating direction. In 1998, a huge debate was 
inaugurated in Germany about the future of area studies that obviously slopped over from the USAmerican discussion that began few years earlier. The end of the East- and Southeast European studies and their integration into the respective home disciplines was announced. These area studies were blamed of being methodologically and theoretically insufficient and backward. ${ }^{49}$ One year after, Holm Sundhaussen reacted by defining a "historical region" called Southeast Europe by the specific overlap or interaction of historical structures, especially produced in the period of the Ottoman Empire. This was not the first attempt to define Southeast Europe as a region specifically compared to the rest of Europe, and implicitly, also specifically compared to the Near East. ${ }^{50}$ Maria Todorova reacted promptly with the blame of essentialism and countered with her concept of historical legacy, which will be discussed below. ${ }^{51}$ Sundhaussen's concept was obviously more attractive to German's academia because it offered an opportunity to slice Europe into clear-cut historic regions and provides seemingly new orientation: southeast, northwest, central, central-east, central-west etc. Even the Black Sea-region did not escape this new fury of slicing Europe geographically into historical regions. ${ }^{52}$

Todorova, however, in this debate has been neglected because of her rejection of geographical parcelling. She introduced the categories of historical legacy and historical perception as heuristic device in describing historical regions and argues that 'historical legacy' and 'historical perception' avoids the danger of essentialism, allows more clearly articulate the dynamism of historical change than structural categories such as border, space, and territoriality. This category would retain the valuable features of the analyses of spatiality and makes it historically more specific. Another advantage according to her is that elements of the historical past are not consciously singled out and encompasses everything that is handed down from the past. ${ }^{53}$ Concretely, she applies her category to Eastern Europe and the Balkans. According to Todorova the most important political legacies of the Balkans are the

\footnotetext{
${ }^{49}$ Baberowski 1998.

${ }^{50}$ Sundhaussen 1999.

51 Todorova 2002, 2005.

${ }^{52}$ Troebst 2007.

53 Todorova 2005, 65-66, 68.
}

Roman, Byzantine, Ottoman, and the communist ones; the most important religious legacies are Judaism, Christianity, and Islam; in social and demographic terms the legacies constitute of large migrations, ethnic diversity, a large and egalitarian agricultural sphere, late urbanization etc. $^{54}$

In the political sphere, the most important legacies until the $19^{\text {th }}$ century would have been the millennium of Byzantine and the half millennium of Ottoman domination. She goes so far stating: "One can argue that the Balkans are, in fact, the Ottoman legacy". ${ }^{55}$ The legacy as continuity began after the continuous break of the Ottoman Empire ceased to exist in the successor states. The break with the legacy was allegedly already completed by the end of WWI; "thereafter it turned into legacy as perception" - in works of historiography, journalism, or everyday discourse, and as important pillar of nationalism. The region has been Europeanizing and the historic Balkans ending. ${ }^{56}$ Socialism would constitute another legacy or another stratum of legacy that covers other territories, including most of the Balkans, and still would be important in different spheres: politics, economy, and society. ${ }^{57}$

Thus we have basically at least two different concepts and one big problem: their arbitrary ghetto-ization in Europe. For both the concepts, the half of a millennium enduring domination of the Ottoman Empire is crucial; for Todorova the Balkans is the Ottoman legacy. It is obvious, however, that the Near East is also an Ottoman legacy, even more pronounced. How comes that the few kilometer wide Bosporus has the magic power to separate one joint historic legacy into two ones, and how comes that this miraculous Bosporus has the magic to separate one historic region from the other although they shared half a millennium of years of Ottoman history, about one thousand years of Byzantine history and about another one thousand years of Ancient Greek, Hellenistic, and Roman history? Why do we neglect that much of what is called Europeaness had been shaped in the Balkans and in the Near East - regions that are considered half-European and non-European today?

\footnotetext{
${ }^{54}$ Ibid. 69.

${ }^{55}$ Ibid.

${ }^{56}$ Ibid. 70-71.

${ }^{57}$ Ibid. 71-74.
} 
As it looks like the period of communism made us Balkanists and Southeast-Europeanists blind for the world beyond the former ideological frontiers. As a consequence of the onset of the transition period beginning with 1989-91 we had to reshape our studies - and we did it, but only half-hearted. This becomes clear if we return to Todorova's argument that the break with the Ottoman legacy was allegedly completed by the end of the WWI. This holds obviously not true for the Near East, not true for Turkey and even not true for the Balkans. Colonialism and its legacy in the Near East, Kemalism and its legacy in Turkey, Communism and its legacy in the Balkans seemingly have erased the Ottoman legacy. This point of view, however, is questionable. It seems that we have missed to investigate the common legacy or imprint that is still at work.

\section{Conclusions}

The contemporary world characterized by globalization is seemingly forming a single and unified environment for intellectual ambition and science, but global networks have also differentiated the contexts of human activity, experience, and knowing. Globalization and diversification move together. Compiling data on the entire world's areas remains fundamental for knowing the world and even for understanding globalization itself, ${ }^{58}$ although the areas have lost their former distinctiveness. The inescapable conclusion is that area studies are still vital. Firstly, area studies still must challenge the disciplines and temper their claims to universal relevance. Secondly, the fluid concept of globalization can be made more precise and meaningful by being grounded in area studies. Viewing globalization from the vantage point of particular localities necessitates the displacement of totalizing theories of globalization with the recognition that globalization has assumed diverse forms connected to unequal power relations. Thus, globalization in itself by no means calls for the abandonment of newly conceived area studies. ${ }^{59}$

Within the context of globalization, the exact knowledge of local, regional and transnational as well as transcultural knowledge gains momen-

\footnotetext{
${ }^{58}$ Ludden 2003, 132.

${ }^{59}$ Mirsepassi et al. 2003, 12-13.
}

tum. The essentialism of the linkage of culture and space, however, becomes questioned; space becomes re-territorialized in relation to the local and the global. One has to avoid the trap of anew closed 'cultural spaces'. Regions as such do not constitute areas of research. Processes such as globalization, migration or the end of the Cold War have been changing spaces. Former space concepts have to be dissolved and new open spaces created. One of the most urgent questions for area studies is the process of globalization. This process has to be considered also from the margins and from bottom up in order to see the asymmetric relations of the world regions to each other. The cultural turn dissolved the notion of culture from its regional context. Trans-cultural relations between regions until now have not been considered worth being investigated, are reconsidered. Area studies are determined by cultural exchange processes of localities and regionalities. ${ }^{60}$

Area studies scholarship has to be internationalized. Putting globalization in the perspective of all the various regions of the world rather than seeing it as a single process reveals a vast patchwork of world territories which have been both increasingly integrated and differentiated during the long history of globalization. It might be a good way to begin expanding the scope of newly conceived area studies and collaborations among area studies programs in the context of globalization. ${ }^{61}$

Seen in this light the insistence on the traditional concept of a historical region 'Southeastern Europe' or 'Balkans' with its implicit ahistorical ghetto-ization would be contradictory to the interventions of revitalizing area studies.

Balkan studies are not yet in a crisis but will slither in a crisis if we follow the path of ghetto-ization unreflecting. This concept is no appropriate heuristic device for the world and the community of area students after 1989 any longer. There is an urgent need for re-thinking of Balkan Studies as well as of Near East studies. The historically grown separation of these two disciplinary fields which belong together is a fallacy to be corrected. My paper suggests that the implosion of socialism and the succeedingly un-

\footnotetext{
${ }^{60}$ Hentschke 2005.

${ }^{61}$ Szanton 2003.
} 
folding processes of globalization have impacted the concept of Balkan history in two ways: (1) it suggests to conceive the Balkans as trans-local space as pointed out by Brunnbauer; (2) it suggests even more - the conceptual reunion of the Balkans and the Near East - a territory which because of its long joint history potentially constitute a world region that I would suggest to call Eurasia Minor ${ }^{62}-$ and the conception of Eurasia Minor as trans-local space.

This traditional disciplinary order cannot be revised from the scratch. The first step into the right direction is to see that there is a problem. A second step could be the revision of training programs the most important points of which consists in the study of Eurasian Minor's history and cultures. Finally, a new type of scholar and a new job description is needed, which is in line with a Eurasia Minor as well as global perspective. The study of Eurasia Minor would provide a more appropriate basis for putting globalization in the perspective of various regions of the world and to react to the forces of globalization. Global studies in general and global history study specifically aim at the resolution of questions located on a global level. If we are not able to respond to them, we will fail - not in ten, maybe not in twenty but for sure in thirty years.

\section{Sažetak}

\section{Ispitivanje disciplinarnih granica: Balkanološke studije u globalizirajućem svijetu}

Od 1989. godine, nekad hermetički odvojeni svjetovi, rasli su zajedno. Globalizacija je postala pojam kojim se objašnjava ovaj fenomen - pojam koji, međutim, nije precizno definiran, uključujući i međunarodne sile - tehnološke, ekonomske i kulturne - koje dovode do sve većeg i većeg razvoja svijeta koji nas okružuje. Države su načete u smislu političke, gospodarske i kulturne suverenosti. Globalizacija se - na prvi pogled - uglavnom doživljava kao brisanje granica, kao deteritorijalizacija, koja ojačava homogenizaciju lokaliteta, kultura i društvenih i ekonomskih praksi.

\footnotetext{
${ }^{62}$ Kaser 2011, 2
}

Istoričare često nasmije iznenadno intenziviranje rasprave o globalizaciji, jer je za njih taj proces star već pola tisućljeća. U tom pogledu razdoblje komunizma predstavlja samo mali predah u dugom, trajnom procesu. Ova tvrdnja je dobra, ali previđa činjenicu da se njegov intenzitet značajno izmijenio. Globalizaciju od tada stvaraju društvene nauke, pošto su, paralelno s tim, društvene nauke potaknute globalizacijom. Ovaj složeni proces posebno se tiče područja istraživanja. Ni balkanološke studije nisu izuzetak.

U svojoj prezentaciji ću analizirati mjesto balkanoloških studija u globalizirajućem svijetu. Zaključit ću da još uvijek nismo u krizi, ali njeni osnovni koncepti će stvoriti krizu ukoliko se nastavimo ne osvrtati na tradiciju. Svijet oko nas se ubrzano mijenja. Koncept istorijski definiranih regija postaje ozbiljno upitan, pa čak i kao heurističko sredstvo. Postoji hitna potreba za ponovnim promišljanjem o balkanološkim studijama.

\section{Bibliography}

Appadurai, A. 2001, Grassroots Globalization and the Research Imagination, In: Appadurai, A. (Ed.), Globalization, Durham, London 2001, 1-21.

Baberowski, J. 1998, Das Ende der Osteuropäischen Geschichte. Bemerkungen zur Lage einer geschichtswissenschaftlichen Disziplin, Osteuropa. Zeitschrift für Gegenwartsfragen des Ostens 48, 1998, 784-799.

Brown, L. C. (Ed.) 1996, The Imperial Legacy: The Ottoman Imprint on the Balkans and the Middle East, New York 1996.

Brunnbauer, Ulf. 2011, The Balkan as Trans-Local Space. Entanglement, Movement and History, Südosteuropa Mitteilungen 3, 2011, 78-94.

Eisenstadt, S. N. 2000, Die Vielfalt der Moderne, Weilerswist 2000.

Epple, A. 2007, 'Global History' and 'Area History'. Plädoyer für eine weltgeschichtliche Perspektivierung des Lokalen, In: Schäbler, B. (Ed.), Area Studies und die Welt. Weltregionen und neue Globalgeschichte, Vienna 2007, 90-116.

Ginio, E. / Kaser, K. (Eds.) 2013, Ottoman Legacies in the Contemporary Mediterranean: The Balkans and the Middle East Compared, Jerusalem 2013.

Green, S. E. 2003, The Multiple Worlds of African Studies, In: Mirsepassi, A. / Basu, A. / Weaver, F. (Eds.), Localizing Knowledge in a Globalizing World. Recasting the Area Studies Debate, Syracuse 2003, 137-147.

Haslinger, P. 2006, Die Osteuropäische Geschichte Zwischen Europäischer Geschichte und Globalge- 
schichte? http://hsozkult.geschichte.hu-berlin.de/ forum/id=708\&type $=$ artikel.

Hentschke, F. 2005, Die Zukunft der Area Studies in Deutschland, http://geschichte-transnational.clioonline.net/tagungsberichte.

Inalcik, H. 1996, The Middle East and the Balkans Under the Ottoman Empire: Essays on Economy and Society, Bloomington 1996.

Kaser, K. 2011, The Balkans and the Near East: Introduction to a Shared History, Vienna, Berlin 2011.

Khalidi, R. I. 2003, The Middle East as an Area in an Era of Globalization, In: Mirsepassi, A. / Basu, A. / Weaver, F. (Eds.), Localizing Knowledge in a Globalizing World. Recasting the Area Studies Debate, Syracuse 2003, 171-190.

Komlosy, A. 2011, Globalgeschichte. Methoden und Theorien, Vienna, Cologne, Weimar 2011.

Ludden, D. 2000, Area Studies in the Age of Globalization, Frontiers. The Interdisciplinary Journal of Study Abroad 6, 2000, 1-22.

Ludden, D. 2003, Why Area Studies?, In: Mirsepassi, A. / Basu, A. / Weaver, F. (Eds.) Localizing Knowledge in a Globalizing World. Recasting the Area Studies Debate, Syracuse 2003, 131-136.

Middell, M. 2005, Universalgeschichte, Weltgeschichte, Globalgeschichte, Geschichte der Globalisierung - ein Streit um Worte?, In: Grandner, M. / Rothermund, D. / Schwentker, W (Eds.) Globalisierung und Globalgeschichte, Vienna 2005, 60-82.

Mirsepassi, A. / Basu, A. / Weaver, F. 2003, Knowledge, Power, and Culture, In: Mirsepassi, A. I Basu, A. / Weaver, F. (Eds.) Localizing Knowledge in a Globalizing World. Recasting the Area Studies Debate, Syracuse 2003, 1-21.

Mitchell, T. 2003, Deterritorialization and the Crisis of Social Science, In: Mirsepassi, A. / Basu, A. / Weaver, F. (Eds.) Localizing Knowledge in a Globalizing World. Recasting the Area Studies Debate, Syracuse 2003, 148-170.

Neuburger, M. 2004, The Orient Within. Muslim Minorities and the Negotiation of Nationhood in Modern Bulgaria, Ithaca, London 2004.

Nolte, H. 2006, Osteuropäische und Globalgeschichte bis zum 19. Jahrhundert, http://hsozkult.geschichte.hu-berlin.de/forum $/$ id=728\&type $=$ artikel.

Osterhammel, J. / Petersson, N. P. 2003, Globalization: A Short History, Princeton, Oxford 2003.

Rothermund, D. 2005, Globalgeschichte und Geschichte der Globalisierung, In: Grandner, M. /
Rothermund, D. / Schwentker, W. (Eds.) Globalisierung und Globalgeschichte, Vienna 2005, 12-35.

Said, E. 1978, Orientalism: Western conceptions of the Orient, New York 1978.

Schäbler, B. 2007, Einleitung. Das Studium der Weltreligionen (Areas Studies) zwischen Fachdisziplinen und der Öffnung zum Globalen: Eine wissenschaftsgeschichtliche Annäherung, In: Schäbler, B. (Ed.), Area Studies und die Welt. Weltregionen und neue Globalgeschichte, Vienna 2007, 11-44.

Schäfer, W. 2001, Global Civilizations and Local Cultures. A Crude Look at the Whole, International Sociology 16, 2001, 301-319.

Schäfer, W. 2003, The Global History. Toward a Narrative for Pangaea Two. EWE 14, 2003, 75-88.

Schäfer, W. 2006, From the End of European History to the Globality of World Regions: A Research Perspective, Global Studies Journal 1, 2006, 1-21.

Schevill, F. 1922, The Balkan Penisula and the Near East: A history from the earliest times to the present day, London 1922.

Stolberg, E. 2007, „Der Mond ist kein Kochtopf“: (Ost-) Europäische Geschichte und Globalgeschichte, In: Digitales Handbuch zur Geschichte und Kultur Russlands und Osteuropas, www.vifaost.de/geschichte/handbuch.

Sundhaussen, H. 1999, Europa balcanica. Der Balkan als historischer Raum Europas, Geschichte und Gesellschaft 25, 1999, 626-653.

Szanton, D. L. 2003, The Origin, Nature, and Challenges of Area Studies in the United States, http://repositories.cdlib.org/uciaspubs/editedvolumes/3/1.

Tessler, M. / Nachtwey, J. / Banda, A. 2001, Introduction: The Area Studies Controversy, In: O’Meara, P. / Mehlinger, H. D. / Newman R. M. (Eds.) Changing Perspectives on International Education, Bloomington, Indianapolis 2001, 67-76.

Todorova, M. 2002, Der Balkan als Analysekategorie. Grenzen, Raum, Zeit, Geschichte und Gesellschaft $28,2002,470-492$.

Todorova, M. 2005, Spacing Europe: What is a Historical Region?, East Central Europe/ECE 32, 2005, 59-78.

Troebst, S. 2007, Le Monde méditerranéen - Südosteuropa - Black Sea World. Geschichtsregionen im Süden Europas, In: Schenk, F. B. / Winkler, M. (Eds.) Der Süden. Neue Perspektiven auf eine europäische Geschichtsregion, Frankfurt, New York 2007, 49-73.

Wachtel, A. B. 2008, The Balkans in World History, Oxford 2008. 
